Original Research Article

\title{
Study of analgesic effect of septilin in comparison with aspirin and tramadol in experimentally induced pain in rats
}

\author{
Naveen Avula ${ }^{1 *}$, Sravani Marpu Raghava ${ }^{2}$
}

${ }^{1}$ Department of Pharmacology, Gitam Institute of Medical

Sciences and Research (GIMSR), Rushikonda, Visakhapatnam, Andhrapradesh, India

${ }^{2}$ Department of Pharmacology,

Vishwa Bharathi medical

College, Kurnool,

Andhrapradesh, India

Received: 08 July 2017

Accepted: 29 July 2017

\section{*Correspondence to: \\ Dr. Naveen Avula, \\ Email: a.naveen.gmc@ \\ gmail.com}

Copyright: (C) the author(s), publisher and licensee Medip Academy. This is an openaccess article distributed under the terms of the Creative Commons Attribution NonCommercial License, which permits unrestricted noncommercial use, distribution, and reproduction in any medium, provided the original work is properly cited.

\begin{abstract}
Background: The task of medicine is to preserve and restore health and to relieve suffering. pain is the most common symptom that brings a patient to a physician's attention. There are many NSAIDs and opioid analgesics which have been employed for alleviating pain but none is free from side effects and drug interactions. Therefore search for a new potent, safe and non toxic drug continues. Methods: This animal study was a cross sectional, observational in nature carried out in male Wistar rats. Animals were divided into four groups with six animals in each group. Group I, II, III, IV given normal saline (control), Tab. Septilin (test), Tab. Aspirin (standard 1),Tab. Tramadol (standard2) respectively through oral feeding tube and tested for thermal reaction time on Eddys hot plate at different time intervals. Reaction times had been recorded and evaluated by using one way ANOVA followed by Tukey's post hoc test with the help of Graph pad Prism. The ' $\mathrm{P}$ ' value of $<0.05$ was considered significant.

Results: The test group (Septilin- 500mg/kg) has shown increase in mean reaction time which is higher, when compared to control group and the increase in mean reaction time of test drug is less when compared to standard groups (Aspirin-100mg/kg and Tramadol- $2 \mathrm{mg} / \mathrm{kg}$ ), but is significant i.e. $\mathrm{P}$ value $<0.05$ at 30, 60, 120 min time intervals. Based on the aforementioned findings septilin has analgesic effect but less than that of the standard drugs Aspirin and Tramadol. Conclusions: The test drug Septilin has analgesic effect, but less when compared to Standard drugs Aspirin and Tramadol. To obtain the final assessment, large scale clinical trials may be necessary to prove its efficacy and further use of Septilin in a routine medical practice.
\end{abstract}

Keywords: Analgesic, Aspirin, Eddys hot plate, Pain, Septilin, Tramadol

\section{INTRODUCTION}

pain is universally understood as a signal of disease, it is the most common symptom that brings a patient to a physician's attention.

The function of the pain sensory system is to protect the body and maintain homeostasis. ${ }^{1}$ Pain can be described as the perceptual counterpart of the body's response to stimuli that threatens the integrity of tissues. ${ }^{2}$ It thus serves as a warning system of threats to the organism.
Analgesics relieve pain as a symptom without affecting its cause. These are the agents which selectively relieve pain by acting on the CNS or peripheral pain mechanisms without significantly altering consciousness.

One of the standard drugs in this study is Aspirin which belongs to NSAIDs (non steroidal antiinflammatory drugs) produces severe adverse effects like gastric erosions, haemorrhages, nephrotoxicity, hypersensitivity reactions, acute salicylism, Reye's syndrome in children with feverand drug interactions. ${ }^{3}$ The other standard drug 
Tramadol is a centrally acting opioid analgesic whose mechanism of action is predominantly based on blockade of serotonin reuptake. Tramadol has also been found to inhibit norepinephrine transporter function. Because it is only partially antagonized by naloxone, it is believed to be only a weak mu-receptor agonist. Toxicity includes association with seizures; the drug is relatively contraindicated in patients with a history of epilepsy and for use with other drugs that lower the seizure threshold. ${ }^{4}$

At this juncture, we need to explore for the newer agents with minimum or no adverse effect profile with high efficacy in alleviating pain. In view of this we have choosen a poly herbal preparation containing various herbs and minerals called Septilin. Its main ingredients are Balsamodendronmukul, Sank Bhasma, Maharasnadiqoath, Tinosporacordifolia, Rubiacordifolia, Emblicaofficinalis, Moringapterigosperma, Glycyrrhizaglabra. It is reported to have antiinflammatory, antibacterial, antiexudative, immunomodulatory effects and wound healing properties. $^{5,6}$ It is claimed to buildup resistance to infections and helpful in treatment of chronic stubborn Upper respiratory tract infections, Tonsilitis and dental infections. ${ }^{7}$ Humoral immunity also enhanced by Septilin by increasing the levels of immunoglobulins $(\operatorname{IgG}) .{ }^{8}$ It has minimal side effects and drug interactions. In this study we have evaluated analgesic effect of septilin with standard analgesics.

Recent Indian government initiatives such as establishing AYUSH (Ayurveda, Yoga, Unani, Siddha, Homeopathy) as a separate ministry and allocation of funds to explore the new therapeutic molecules by utilising the indigenous knowledge is a positive move in right direction.

\section{METHODS}

Male wistar rats weighing 200-250gms, were procured from central animal house of Gandhi Medical College, Secunderabad after obtaining permission from the Institutional Animal Ethics Committee for the project. There are several animal models for evaluating the analgesic agents with different stimuli such as thermal, electrical, chemical, mechanical etc. in case of acute pain. ${ }^{9}$ In thermal methods the general principle employed is applying heat or cold to sharply defined areas to elicit a response, and the difference in time needed to elicit the response before and after administration of drug to be evaluated.

- Hot plate method: placement of animal on hot surface.

- The tail flick test: It is widely and reliably used test for revealing the potency of opioid analgesics. In this also heat is used as the noxious stimulus. The stimulus causes a simple nociceptive spinal reflex response in which the rat or mouse flicks its tail away from the heat source. a. Tail flick response by using radiant heat in rats. ${ }^{10}$

b. Tail flick test using immersion of tail in warm water. $^{11}$

\section{Modifications of this test}

- Cold tail flick test. ${ }^{12}$

- Cold ethanol tail flick test. ${ }^{13}$

In the present study thermal stimulus with hot plate method was utilized. Animals were screened for discoordination test to avoid false positive results and were exluded.

\section{Study design}

The animals were devided into 4 groups, 6 animals in each group and given test, standard drugs per oral through oral feeding tube as follows:

- I group: Control - 6 animals

- II group: Test- Tab. Septilin $(500 \mathrm{mg} / \mathrm{kg})-6$ animals.

- III group: Standard 1- Tab. Aspirin (100mg/kg) - 6 animals.

- IV group: Standard 2- Cap. Tramadol $2 \mathrm{mg} / \mathrm{kg}-6$ animals

The study was carried out by hot plate method. When animal is placed on the Eddys hot plate, behavioral changes are produced like paw licking and jumping. The time taken for these responses to occur had been measured which is called latency period or reaction time. Animal was placed gently on the hot plate through upper lid and stop - watch was immediately pressed on. The animal was visualized carefully through the transparent wall for noting the characteristic cut off responses. As soon as the animal responded to noxious stimulus, the stop - watch was shut off and the animal taken away from the hot plate and the reaction time was recorded.

- Initially readings have been taken before administration of drugs. That represents reaction times at 0 minute.

- Then the drugs were given per oral by using oral feeding tube. The animals are placed on hot plate which is maintained at $55^{\circ} \mathrm{C}$ and the latency period or reaction time is recorded using stop watch (Latency period is the period when animals are placed and until response occur like licking of paws and jumping). Reaction times of different groups obtained after 30minutes, 60minutes and 120 minutes of interval after drug administration. In this way readings were taken and tabulated.

\section{RESULTS}

The analgesic activity is based on increase in mean reaction time of inflammatory pain to thermal stimulus on Hot plate method. 
Percentage increase in reaction time is calculated at different time intervals by using the following formula.

$=\underline{\text { mean reaction time in test group }- \text { mean reaction time in control }} \times 100$ Mean reaction time in test group

The results have been statistically analyzed for significance by using one way analysis of variance (ANOVA) for multiple group comparisons followed by Post Hoc Tukey's test with the help of Graph pad Prism.

' $F$ ' value was calculated using the formula.

$\mathrm{F}=$ Variance between groups $\div$ variance within group. ${ }^{14}$
Table 1 shows Mean \pm SD of reaction time in different groups at different time intervals.

It shows that test drug Septilin has increased the reaction time at different time intervals such as at zero min the reaction time is 2.48 seconds, then at $30 \mathrm{~min} 6.14$ seconds, at $60 \mathrm{~min} 9.32$ seconds and at $120 \mathrm{~min}$ it was 8 seconds. Standard drug1 Aspirin produced $2.57 \mathrm{sec}, 7.96 \mathrm{sec}, 12.07$ $\mathrm{sec}, 10.22 \mathrm{sec}$ as reaction times at zero, $30 \mathrm{~min}, 60 \mathrm{~min}$, 120min intervals respectively. Standard drug 2 produced $2.55 \mathrm{sec}, 11.01 \mathrm{sec}, 14.05 \mathrm{sec}, 12.37 \mathrm{sec}$ as reaction times at zero, $30 \mathrm{~min}, 60 \mathrm{~min}, 120 \mathrm{~min}$ intervals respectively.

Table 1: Mean \pm SD values of reaction time in different groups.

\begin{tabular}{|llllll|}
\hline \multirow{2}{*}{ Group } & Dose $(\mathbf{m g} / \mathbf{k g})$ & \multicolumn{4}{l}{ Reaction time in seconds at time intervals } \\
\cline { 3 - 6 } & & $\mathbf{0}$ min & $\mathbf{3 0}$ min & $\mathbf{6 0}$ min & $\mathbf{1 2 0}$ min \\
\hline Control & & $2.47 \pm 0.12$ & $2.52 \pm 0.11$ & $2.39 \pm 0.08$ & $2.51 \pm 0.14$ \\
\hline Septilin & 500 & $2.48 \pm 0.13$ & $6.14 \pm 0.19$ & $9.32 \pm 0.49$ & $8.00 \pm 0.23$ \\
\hline Aspirin & 100 & $2.57 \pm 0.13$ & $7.96 \pm 0.39$ & $12.07 \pm 0.23$ & $10.22 \pm 0.21$ \\
\hline Tramadol & 2 & $2.55 \pm 0.13$ & $11.01 \pm 0.34$ & $14.05 \pm 0.23$ & $12.37 \pm 0.35$ \\
\hline
\end{tabular}

Number of animals in each group $(\mathrm{n}=6)$

Values are mean \pm SD (standard deviation)

Table 2 shows mean percentage increase in reaction time in different groups at different intervals.

Overall mean percentage increase in reaction time is higher with Tramadol (79.93\%) compared to Aspirin (74.65\%) and Septilin (67.30\%).

Table 2: Percentage increase in reaction time at different time intervals compared to control.

\begin{tabular}{|lllll|}
\hline Group & 30 min & 60 min & 120 min & Mean \\
\hline Septilin & 58.95 & 74.35 & 68.62 & 67.30 \\
\hline Aspirin & 68.34 & 80.19 & 75.44 & 74.65 \\
\hline Tramadol & 77.11 & 82.98 & 79.70 & 79.93 \\
\hline
\end{tabular}

Number of animals in each group $(n=6)$

Table 3 to Table 10 gives statistical analysis of results at 0, 30, 60 and 120 min using one way ANOVA followed by Tukey's post hoc test. Group The ' $\mathrm{P}$ ' value of $<0.05$ was considered significant.

Table 3: Statistical analysis shows comparison of reaction time between different groups at $0 \mathrm{~min}$.

\begin{tabular}{|llll|}
\hline Groups & Mean \pm SD & F - value* & Significance \\
\hline Control & $2.47 \pm 0.12$ & & \\
\cline { 1 - 1 } Septilin & $2.58 \pm 0.13$ & & \\
\cline { 1 - 1 } Aspirin & $2.57 \pm 0.13$ & $\mathrm{P}=0.41, \mathrm{NS}$ \\
\hline Tramadol & $2.57 \pm 0.13$ & \\
\hline
\end{tabular}

*One way ANOVA NS- Not Significant
Table 3 and 4 represents reaction times of different groups and group wise comparison at 0 min respectively.

Table 4: Group wise comparison of reaction times at 0 min.

\begin{tabular}{|llll|}
\hline $\begin{array}{l}\text { Groups } \\
\text { compared }\end{array}$ & $\begin{array}{l}\text { Mean } \\
\text { difference }\end{array}$ & $\mathbf{P < 0 . 0 5 *}$ & Summary \\
\hline $\begin{array}{l}\text { Control vs } \\
\text { Septilin }\end{array}$ & 2.13 & $\mathrm{~N}$ & $\mathrm{NS}$ \\
\hline $\begin{array}{l}\text { Control vs } \\
\text { Aspirin }\end{array}$ & 1.93 & $\mathrm{~N}$ & $\mathrm{NS}$ \\
\hline $\begin{array}{l}\text { Control vs } \\
\text { Tramadol }\end{array}$ & 1.93 & $\mathrm{~N}$ & $\mathrm{NS}$ \\
\hline $\begin{array}{l}\text { Septilinvs } \\
\text { Aspirin }\end{array}$ & 0.19 & $\mathrm{~N}$ & $\mathrm{NS}$ \\
\hline $\begin{array}{l}\text { Septilinvs } \\
\text { Tramadol }\end{array}$ & 0.19 & $\mathrm{~N}$ & $\mathrm{NS}$ \\
\hline $\begin{array}{l}\text { Aspirin vs } \\
\text { Tramadol }\end{array}$ & 0 & $\mathrm{~N}$ & $\mathrm{NS}$ \\
\hline
\end{tabular}

N - NO; S- significant; *post - hoc Tukey's test

Table 5: Statistical analysis shows comparison of reaction time between different groups at $30 \mathrm{~min}$.

\begin{tabular}{|llll|}
\hline Groups & Mean \pm SD & F- value* & Significance \\
\hline Control & $2.52 \pm 0.11$ & & \\
\cline { 1 - 1 } Septilin & $6.14 \pm 0.19$ & & $\mathrm{P}=<0.0001$ \\
\hline Aspirin & $7.96 \pm 0.39$ & & $\mathrm{~S}$ \\
\hline Tramadol & $11.01 \pm 0.34$ & & \\
\hline *One way ANOVA S- significant & \\
\hline
\end{tabular}


Table 6: Group wise comparison of reaction times at $30 \mathrm{~min}$.

\begin{tabular}{|llll|}
\hline $\begin{array}{l}\text { Groups } \\
\text { compared }\end{array}$ & $\begin{array}{l}\text { Mean } \\
\text { difference }\end{array}$ & $\mathbf{P}<\mathbf{0 . 0 5 *}$ & Summary \\
\hline $\begin{array}{l}\text { Control vs } \\
\text { Septilin }\end{array}$ & 31.35 & $\mathrm{Y}$ & $\mathrm{S}$ \\
\hline $\begin{array}{l}\text { Control vs } \\
\text { Aspirin }\end{array}$ & 47.11 & $\mathrm{Y}$ & $\mathrm{S}$ \\
\hline $\begin{array}{l}\text { Control vs } \\
\text { Tramadol }\end{array}$ & 73.52 & $\mathrm{Y}$ & $\mathrm{S}$ \\
\hline $\begin{array}{l}\text { Septilinvs } \\
\text { Aspirin }\end{array}$ & 15.76 & $\mathrm{Y}$ & $\mathrm{S}$ \\
\hline $\begin{array}{l}\text { Septilinvs } \\
\text { Tramadol }\end{array}$ & 42.17 & $\mathrm{Y}$ & $\mathrm{S}$ \\
\hline $\begin{array}{l}\text { Aspirin vs } \\
\text { Tramadol }\end{array}$ & 26.41 & $\mathrm{Y}$ & $\mathrm{S}$ \\
\hline
\end{tabular}

Y - Yes; N - No; S- significant

*post - hoc Tukey's test

Table 7: Statistical analysis shows comparison of reaction time between different groups at $60 \mathrm{~min}$.

\begin{tabular}{|llll|}
\hline Groups & Mean \pm SD & F- value* & Significance \\
\hline Control & $2.39 \pm 0.08$ & & \\
\cline { 1 - 1 } Septilin & $9.32 \pm 0.49$ & & $\mathrm{P}=<0.0001$ \\
\cline { 1 - 1 } Aspirin & $12.07 \pm 0.23$ & & $\mathrm{~S}$ \\
\cline { 1 - 2 } Tramadol & $14.05 \pm 0.23$ & & \\
\hline
\end{tabular}

*One way ANOVA S- significant

Table 8: Group wise comparison of reaction times at $60 \mathrm{~min}$.

\begin{tabular}{|llll|}
\hline $\begin{array}{l}\text { Groups } \\
\text { compared } \\
\text { Control } \\
\text { vsseptilin }\end{array}$ & $\begin{array}{l}\text { Mean } \\
\text { difference }\end{array}$ & $\mathbf{P}<\mathbf{0 . 0 5 *}$ & Summary \\
\hline $\begin{array}{l}\text { Control vs } \\
\text { Aspirin }\end{array}$ & 79.03 & $\mathrm{Y}$ & $\mathrm{S}$ \\
\hline $\begin{array}{l}\text { Control vs } \\
\text { Tramadol }\end{array}$ & 95.20 & $\mathrm{Y}$ & $\mathrm{S}$ \\
\hline $\begin{array}{l}\text { Septilinvs } \\
\text { Aspirin }\end{array}$ & 22.45 & $\mathrm{Y}$ & $\mathrm{S}$ \\
\hline $\begin{array}{l}\text { Septilinvs } \\
\text { Tramadol }\end{array}$ & 38.62 & $\mathrm{Y}$ & $\mathrm{S}$ \\
\hline $\begin{array}{l}\text { Aspirin vs } \\
\text { Tramadol }\end{array}$ & 16.16 & $\mathrm{Y}$ & $\mathrm{S}$ \\
\hline
\end{tabular}

Y - Yes; N - No; S- significant

*post - hoc Tukey's test

Table 9: Statistical analysis shows comparison of reaction time between different groups at $120 \mathrm{~min}$.

\begin{tabular}{|llll|}
\hline Groups & Mean \pm SD & F- value* & Significance \\
\hline Control & $2.51 \pm 0.14$ & & \\
\cline { 1 - 1 } Septilin & $8.00 \pm 0.23$ & & $\mathrm{P}=<0.0001$ \\
\cline { 1 - 1 } Aspirin & $10.22 \pm 0.21$ & & $\mathrm{~S}$ \\
\cline { 1 - 2 } Tramadol & $12.37 \pm 0.35$ & & \\
\hline
\end{tabular}

*One way ANOVA S- significant
Similarly, tables 5 and 6 at $30 \mathrm{~min}$, table 7 and 8 at $60 \mathrm{~min}$, Tables 9 and 10 at $120 \mathrm{~min}$.

Table 10: Group wise comparison of reaction times at 120 min.

\begin{tabular}{|llll|}
\hline $\begin{array}{l}\text { Groups } \\
\text { compared }\end{array}$ & $\begin{array}{l}\text { Mean } \\
\text { difference }\end{array}$ & P<0.05* & Summary \\
\hline $\begin{array}{l}\text { Control vs } \\
\text { Septilin }\end{array}$ & 54.90 & $\mathrm{Y}$ & $\mathrm{S}$ \\
\hline $\begin{array}{l}\text { Control vs } \\
\text { Aspirin }\end{array}$ & 77.10 & $\mathrm{Y}$ & $\mathrm{S}$ \\
\hline $\begin{array}{l}\text { Control vs } \\
\text { Tramadol }\end{array}$ & 98.60 & $\mathrm{Y}$ & $\mathrm{S}$ \\
\hline $\begin{array}{l}\text { Septilinvs } \\
\text { Aspirin }\end{array}$ & 22.20 & $\mathrm{Y}$ & $\mathrm{S}$ \\
\hline $\begin{array}{l}\text { Septilinvs } \\
\text { Tramadol }\end{array}$ & 43.69 & $\mathrm{Y}$ & $\mathrm{S}$ \\
\hline $\begin{array}{l}\text { Aspirin vs } \\
\text { Tramadol }\end{array}$ & 21.49 & $\mathrm{Y}$ & $\mathrm{S}$ \\
\hline
\end{tabular}

Y - Yes; N - No; S- significant

*post - hoc Tukey's test

These tables represent reaction times of single group recordings with rest of the groups.

\section{DISCUSSION}

In this study the analgesic effect of Septilin has been compared with standard drugs Aspirin and Tramadol. There has been an increase in mean reaction time at time interval 30, 60 and $120 \mathrm{~min}$ to thermal stimulus is observed.

The test drug Septilin and standard drugs Aspirin, Tramadol are showing increase in mean reaction time when compared to control and maximum at $60 \mathrm{~min}$ after drug administration. The test group (Septilin- $500 \mathrm{mg} / \mathrm{kg}$ ) is showing increase in mean reaction time which is higher, when compared to control and the increase in mean reaction time of test drug is less when compared to standard groups (Aspirin-100mg/kg and Tramadol$2 \mathrm{mg} / \mathrm{kg}$ ), but is significant i.e. $\mathrm{P}$ value $<0.05$ at $30,60,120$ min time intervals.

Septilin $(500 \mathrm{mg} / \mathrm{kg})$ has analgesic effect but less than that of the standard drugs Aspirin $(100 \mathrm{mg} / \mathrm{kg})$ and Tramadol $(2 \mathrm{mg} / \mathrm{kg})$. To obtain the final assessment, large scale clinical trials may be necessary to prove its efficacy and further use of Septilin in different kinds of pain treatment schedule as a routine medicine.

Previously a study done by Khanna, N. and Sharma, S.B. shown analgesic effect of septilin with different kind of pain models like Tail flick method and Glacial acetic acid - induced writhing test in mice.

The exact mechanism of action of Septilin is still unknown, but it may probably act by inhibition of Cyclo- 
oxygenase (COX) enzyme. ${ }^{15}$ This article also supports the analgesic activity of Septilin.

\section{ACKNOWLEDGEMENTS}

Authors would like to thank to the staff and his colleagues of Gandhi Medical College for their scientific inputs and cooperation throughout the study.

\section{Funding: No funding sources}

Conflict of interest: None declared

Ethical approval: The study was approved by the Institutional Ethics Committee (IAEC/GMC/2012/5)

\section{REFERENCES}

1. Fauci, Braunwald, Kasper, Hauser, Longo. Harrison's Internal medicine, Chapter 11. Pain: Pathophysiology and management, $18^{\text {th }}$ Edition; 275.

2. Treede RD, Meyer RA, Raja SN, Campbell JN. Peripheral and central mechanisms of cutaneous hyperalgesia. Progress in neurobiology. 1992 Apr 30;38(4):397-421.

3. Goodman and Gilman's The pharmacological basis of therapeutics, $12^{\text {th }} \mathrm{Ed}$; chapter - Anti - Inflammatory, Antipyretic and Analgesic agents; Pharmacotherapy of Gout- Tilo Grosser, Emer Smyth and Garret A. Fitzgerald: New York: McGraw-Hill; 1996:964.

4. Katzung BG, Susan BM, Trevor AJ. Basic and Clinical Pharmacology, 12 $2^{\text {th }}$ Ed, chapter- Opioid Analgesics \& Antagonists:559.

5. Khanna N, Sharma SB. Anti-inflammatory and analgesic effect of herbal preparation: Septilin, 2001;55:195-202.

6. Udupa AL, Gurumadhvarao S, Kulkarni DR. Wound healing profile of Septilin. Ind J Physiol Pharmac. 1989;33(1):39-42.
7. Nigam P, Kapoor KK, Singh R, Agarwal AK, Gupta AK. Septilin Upper respiratory tract infections. The Medicine and Surgery. 1985;2:28.

8. Daswani BR, Hegnanarayan RY. Immunomodulatory Activity of Septilin, a Poly herbal preparation. Phytotherapy Research. 2002;16:162-5.

9. Ghosh MN. Fundamentals of Experimental Pharmacology, 4thed, some common evaluation techniques: 162.

10. Geller I, Axelor LR. Methods for evaluating analgesics in laboratory animals. In Soulairac A, Cahn J, Charpentier J (Eds): Pain. Acad Press; 1968:153-63.

11. Sewell RDE, Spencer PSJ. Antinociceptive activity of narcotic agonist and partial agonist analgesics and other agents in the tail immersion test in mice and rats. Neuropharmacol. 1976;15:683-8.

12. Pizziketti RJ, Pressman NS, Geller EB, Cowan A, Adler MW. Rat cold water tail-flick: a novel analgesic test that distinguishes opioid agonists from mixed agonist-antagonists. Eur J Pharmacol. 1985;119:23-9.

13. Wang JJ, Ho ST, Hu OY, Chu KM. An innovative cold tail-flick test: the cold ethanol tail-flick test. Anesth Analg. 1995;80:102-7.

14. Mahajan BK. methods in biostatistics, $5^{\text {th }} \mathrm{Ed}$, Chapter - significance of difference in means: 129-153.

15. Varma SR, Ashok G, Vidyashankar S, Patki P, Nandakumar KS. Antiinflammatory properties of Septilin in Lipopolysaccharide activated monocytes and macrophages. 2011;33(1):55-63.

Cite this article as: Avula N, Sravani MR. Study of analgesic effect of septilin in comparison with aspirin and tramadol in experimentally induced pain in rats. Int J Basic Clin Pharmacol 2017;6:2271-5. 